\title{
Demography of Conflict and the Herders-Farmers Crisis in Nigeria
}

\author{
Emmanuel Nwakanma ${ }^{1}$ \\ Stanley Ebitare Boroh ${ }^{2}$
}

Department of Sociology 1

University of Port Harcourt, Rivers, Nigeria

Department of Sociology and Anthropology ${ }^{2}$

Federal University Otuoke, Bayelsa, Nigeria

\begin{abstract}
The worsening violence between Farmers and Nomadic herdsmen in Nigeria has remained an issue of concern on the laundry list of the Nigerian State, policy makers, security agencies, International bodies as well as Social science scholars. While conflict is considered a normal and inevitable outcome of human relationships, the concern here is the devastating socio-economic, political and environmental implications of the conflict between these two livelihood groups as well as its impact on national development. Whereas a number of factors have been adduced for this growing violence ranging from climatic transformations, deteriorating environmental conditions, desertification, soil degradation; political and ethnic strife; breakdown in traditional conflict resolution mechanisms; proliferation of arms in the country and a dysfunctional legal regime that neglects justice; this paper, relying on the demographic theory of conflict, demonstrates how population overshoot in Nigeria explicate the new violent and widespread dimensions of the Farmers-Herders conflict. This paper, relying on the Demographic theory of conflict, argues that among the various causes of the Farmers-Herders conflict, the exponential growth of Nigeria's population and the inability of the Nigerian State to meet the needs of the populace, contributes to the endless contest for space and property in the country, referred to in this paper as 'population induced warfare'. In line with this thesis, this paper recommends that Nigeria as a country should begin to pay serious attention to the costs and impacts of population growth and create accordingly, rights-based population policies that adapts Nigeria's population strength to a positive force for sustainable development.
\end{abstract}

Keywords: Conflict, demography, herders-farmers crisis, population, sustainable development

\section{Introduction}

The history of Nigeria is replete with conflict of various dimensions, ranging from religious to sectional violence, and to the currently escalating clashes between livelihood groups, particularly between sedentary farmers and itinerant herdsmen across the country. As noted by Dalhatu (2012), Muzan (2014) and Peace Direct (2017) amid the very many complex socio-political problems facing Nigeria, conflict and issues of national disunity remain prevalent. In 1967 the Nigerian state was confronted with a civil war with 
Biafran separatists resulting in the death of millions of people and massive destruction of property. Grievances in the Igbo community were again reignited in 2015 in protests by Igbo youths and the Indigenous People of Biafra (IPOB) group who still feel that the Nigerian state is yet to resolve the issues that culminated into the civil war. Between 2006 and 2009, following series of agitations for good and inclusive governance by various groups including the Major Isaac Jasper Adaka Boro led movement of 1966, a militant group named MEND alongside many other armed militias of the Niger Delta region protested against the increasing environmental degradation and poverty in the region in spite of the wealth generated from the region. The activities of these groups also impacted significantly on the social, economic and political growth of the country resulting in loss of lives and property. Prominent also in the history of conflict in Nigeria is the ongoing terror campaign and humanitarian crisis in the Northern part of Nigeria which has claimed the lives of over 20,000 people and displaced more than 2.6 million persons (Peace Direct, 2017). The current concern on the front burner of Nigeria's security and development today is the intensified violence between Cattle Herdsmen and Rural Farmers in the country.

As noted by International Crisis Group (ICG) (2017) and Erondu \& Nwakanma (2018) the violent conflicts between nomadic cattle herders, who are largely Fulani's and sedentary agrarian communities in the central and southern zones of Nigeria have escalated in recent years and have assumed various dangerous dimensions threatening the country's security and stability. The ICG (2017) and Sahara Reporters (2018) opine that with an estimated death toll of approximately 2,500 people in 2016 and over 300 in the first quarter of 2018, these clashes are becoming as potentially dangerous as the Boko Haram insurgency in the North East, Nigeria. While conflicts and violent clashes between farmers and nomadic cattle herders have been a common feature of economic livelihood in West Africa since time immemorial, the recent increase in the violence and the application of dangerous weapons as well as the systematization of the attacks have revealed a worrisome dimension to this seemingly recalcitrant social problem in Nigeria. The concern now is the immediate and impending implications of this feud, especially as it directly impacts on peace, stability, human development, economic growth and sustainable development (Erondu \& Nwakanma, 2018). This paper concerns itself with the various issues contributing to population overshoot in Nigeria and the demographic dimensions of the Farmers-Herdsmen crisis in Nigeria.

\section{Theoretical Framework}

The perennial nature of the clashes between itinerant cattle Herders and pastoralist Farmers in Nigeria informs the growing concern for viable and lasting methods to improve on the relationship between these coexisting livelihood groups. Conflict between these two groups over space and ownership of natural resources has a long history throughout sub-Saharan Africa. As noted by Moritz (2010) conflict between farmers and pastoralist 
have remained a constant occurrence in West Africa. While they have coexisted in symbiotic relationships, there have been pockets of violence between these two groups in many West African communities. Fights over cattle have claimed thousands of lives in South Sudan and the Central African Republic, worsening the humanitarian crises in two states devastated by civil war. Militias raised by armed cattle herders have brought anarchy to parts of northern Kenya, killing farmers white and black (The Telegraph, 2018). A Nigerian Environmental Study Team (NEST) report of 1991 revealed that long before these recent clashes in Nigeria, Fulani cattle herders and farmers have always contended, at times violently, with each other for space and natural resources in places Bornu, Benue, the then Gongola and Plateau States. Davidheiser and Luna (2008) noted that the clashes between these two groups are usually provoked conflict between these groups emerge as a result several historical, social and environmental factors such as climate changes, drought, famine, international development projects, demographic changes, environmental degradation, ownership and utilization of available land, water resources and vegetal resources. However, today, this perennial crisis has assumed worrisome dimensions that pose serious threat to national cohesion and growth. As noted by Nwosu (2017), while an accurate account of the death toll resulting from herdsmen-farmer violence in Nigeria is difficult to come by due to the lack of a dedicated database, newspaper reports of various incidents involving the herdsmen and farmers in settled communities reveal that the conflicts have resulted in the loss of over 60,000 lives since 2001, making it deadlier than the notorious Boko Haram uprising. A BBC report also claims that over 50,000 persons have been killed in the crisis between 2001 and 2004 and over 62, 000 person displaced in the Middle belt states of Benue, Kaduna, Nassarawa and Plateau alone. Sadly, women and children accounted for almost 35,000 of these deaths (Nwosu, 2017; Kwaja \& Ademola-Adelehin, 2018). Another study provided an estimate of the economic cost of the HerdsmenFarmer conflicts in four states of Benue, Kaduna, Nassarawa and Plateau, positing that about $\$ 14$ billion is lost annually to destruction of property, agricultural product, and the management of the Herdsmen-Farmers crisis (Nwosu, 2017).

The frequency and intensity of these clashes has increased in recent times spreading even to communities beyond the Middle Belt States. One of the most prominent recent clashes allegedly perpetrated by cattle herders was the Agatu Massacre in Benue State where about 300 Agatu indigenes in four communities were massacred in cold blood, and more than 7,000 persons displaced from their homes. As noted by Davidheiser \& Luna (2008); Nwosu (2017); Ajibefun (2018) these killings were accompanied by the destruction of houses and other property, rape, as well as illegitimate occupation of victim communities. Further South, on 25 April 2016, suspected armed herders invaded Ukpabi Nimbo, an agrarian community in Enugu State, in a reprisal attack, killing about 40 indigenes. Similar cases of herder-farmer conflicts have been reported in Zamfara and Katsina States in the North, as well as Abia and 
Osun States in the South-East and South-West respectively (Channels, 2017; Nwosu, 2017; Odunsi, 2017).

According to the ICG (2017) the spread of this conflict into Southern states in Nigeria is aggravating already fragile relations among the country's major regional, ethnic and religious groups. Many have argued that the attacks largely carried out by the Herders on perceived hostile communities is a systematic ethnic cleansing; while the South's majority Christian communities resent the influx of predominantly Fulani-Muslim herders, portrayed in some narratives as an "Islamization" programme of the North (Onwuka, 2017; Telegraph, 2018). The implications of these are enormous as they tend to provoke ethnic, religious and political crisis in the country.

\section{Trends and Drivers of Herders-Farmers conflict in Nigeria}

Over the last decade violent clashes between Cattle Herders and Rural farmers across communities in Sub-Saharan Africa, including Nigeria, have increased exponentially with a lot of factors adduced as its causes. Kwaja \& AdemolaAdelehin (2018) noted that from Mali to South Sudan, Democratic Republic of Congo to Nigeria, climate variability, environmental degradation, and sociopolitical upheaval have shifted pastoralist migratory patterns and increased tensions between farmers and herders. These changes have increased confrontations between this two livelihood groups leading to violent conflict, deaths, forced displacement and migration, erosion of inter-communal relationships, as well as the destruction of agricultural and livestock outputs (Mercy Corps, 2015).

Sinclair \& Fryxell (1985) posit that the introduction of new irrigation technology and modern farming techniques into Africa through development projects allowed for the expansion of agriculture into relatively arid regions which caused many farmers in the Sahel to expand into semi-arid regions traditionally used by cattle Herders as grazing lands. For Van den Brink, Bromley and Chavas (1995) cited in Davidheiser \& Luna (2008), exclusive property regimes' in colonial and postcolonial Africa have also contributed to the overuse of the resource base, amplification of negative effects of drought periods, and increased conflicts between nomads and farmers. The United States Agency for International Development (USAID) in 1996 explained how poor pastures conditions in Niger and Mali have caused herders there to bring their animals to Burkina Faso, straining Burkina's pasture resources. Areas where water is available are particularly subject to overgrazing. The increasing use of traditional pasturelands for crop production - particularly along the border with Mali - has aggravated the situation and has led to increasing conflict between agriculturalists and pastoralists (USAID, 1996).

Within Nigeria, industrialization, urbanization, climate changes, expansion of farms as well as the advancement of the Sahara Desert has blocked many traditional grazing routes used by herders moving south as the Sahara Desert advances in northern Nigeria. Environmental change in neighbouring countries, such as the shrinkage of Lake Chad, have also caused a migration of foreign 
herders whose lack of familiarity with Nigerian populations often escalate violent misunderstandings. ICG (2017) and Kwaja \& Ademola-Adelehin (2018) further noted that frequent droughts and desertification; loss of northern grazing lands to the expansion of human settlements; new livestock and farming practices; rural banditry and cattle rustling, etc, further exacerbate everyday conflict between these two groups. As a matter of fact, much of the clashes recorded between these groups are largely reprisals on perceived hostility and unwarranted harassments by members of both livelihood groups. As noted by Nwosu (2017) allegations of cattle rustling are at the heart of some of the clashes as Herdsmen frequently justify their attacks on settled communities with allegations that affected communities steal their cattle and murder their colleagues and children. According to Mr. Mohammed Abdullahi, the Chairman of the Miyetti Allah Cattle Breeders Association (MACBA), in Plateau State, this act has necessitated their bearing arms for defence since the government has failed to protect them from rustlers and bandits (Nwosu, 2017).

Another worrisome issue in the Herders-Farmers crisis is the free flow of criminals and bandits from neighbouring countries into Nigeria's porous borders. As noted by Nwosu (2017) most of the attacks allegedly perpetrated by herdsmen can be traced to foreign transhumant Fulani's and many other armed groups especially from Libya, who move around unregulated offering services as war mercenaries, bandits, and armed robbers. Though Nigeria has no direct boundary with Libya, some quarters have linked escaping rebels trained by Muammar Gaddafi to the spate of killings across Nigeria. These new trends have further expanded the concern on how best to tackle this challenge and create a safe environment for Nigerians in the face of the various factors capable of escalating violence in Nigeria including the problem of population overshoot.

\section{Population growth, Resource Scarcity and Conflict}

Since the end of the Second World War and an assessment of its impact on human society, scholars have made various attempts to understand the underlying causes of conflict and violence in the society; with the following identified as prime causal factors: human innate aggressive nature, social inequality, deprivation and poverty, issues of legitimacy, forced migration, ethnicity, religious extremism, and resource scarcity. Prominent amongst these perspectives is the resource scarcity model which argues that rapid population growth is one of the major causes of scarcity of resources, which then triggers armed conflict, predominantly in developing countries (Urdal, 2007; Dabelko, 2011). Resource scarcity here explains the lack of availability of supplies required to maintain life, or a certain quality of life. Scarcity, as an economic concept, assumes that humans have unlimited wants which must be fulfilled in the face of finite available scarce resources, which tends to generate intra and intergroup conflicts.

An analysis of the complex interactive effects of population growth on society and of the broad system of factors driving conflict in developing 
countries by scholars such as Barbier (1999); Maxwell \& Reuveny (2000); Urdal (2007); Bretschger (2008) and Dabelko (2011), revealed that the pressures of population growth, economic growth and climate change are placing incredible stress on finite natural resources such as fossil fuels and minerals, including land, potable water, etc. Demands for these resources intensify as population increases and new actors join the competition for the world's remaining deposits of resources.

Although population statistics were before now imprecise, the world population, according to Worldometers (2018), was estimated to be around 5 million at the dawn of agriculture in 8000 B.C. Over the 8,000-year period up to 1 A.D, world population grew to about 300 million with a growth rate of under $0.05 \%$ per year. A tremendous change occurred with the industrial revolution resulting in a rapid increase in world population from around 300 million to over 5 billion 1987. Today the World population stands at 7,632,819,325 persons (Worldometers, 2018). Furthermore, a world population review of 2018 revealed that human population across the globe grew from $6,789,771,253$ in 2008 to $7,632,819,325$ in 2018 at a yearly change of $1.24 \%$. The table 1 below shows world population growth per year, including the percentage of yearly changes, net changes, density, urban population and urban population percent per year; while table 2 shows the world population forecast from year 2020 to year 2050, including the percentage of yearly changes and the fertility rate per year. From the table 2 below, we can see that at a yearly change rate of about $1 \%$ and a fertility rate of $2.47 \%$, world population is expected to increase from 7,795,482,309 in 2020 to $9,771,822,753$ to 2050 .

Table 1: World Population growth from 2008 to 2018

\begin{tabular}{|c|c|c|c|c|c|c|}
\hline Year & $\begin{array}{c}\text { World } \\
\text { Population } \\
\end{array}$ & $\begin{array}{c}\text { Yearly } \\
\text { Change }\end{array}$ & Net Change & $\begin{array}{l}\text { Density } \\
\left(\mathbf{P} / \mathbf{K m}^{2}\right) \\
\end{array}$ & Urban Pop & Urban Pop \% \\
\hline 2018 & $7,632,819,325$ & $1.09 \%$ & $82,557,224$ & 51 & $4,186,975,665$ & $55 \%$ \\
\hline 2017 & $7,550,262,101$ & $1.12 \%$ & $83,297,821$ & 51 & $4,110,778,369$ & $54 \%$ \\
\hline 2016 & $7,466,964,280$ & $1.14 \%$ & $83,955,460$ & 50 & $4,034,193,153$ & $54 \%$ \\
\hline 2015 & 7,383,008,820 & $1.16 \%$ & $84,555,787$ & 50 & $3,957,285,013$ & $54 \%$ \\
\hline 2014 & $7,298,453,033$ & $1.18 \%$ & $85,026,581$ & 49 & $3,880,128,255$ & $53 \%$ \\
\hline 2013 & $7,213,426,452$ & $1.20 \%$ & $85,249,517$ & 48 & $3,802,824,481$ & $53 \%$ \\
\hline 2012 & $7,128,176,935$ & $1.21 \%$ & $85,168,349$ & 48 & $3,725,502,442$ & $52 \%$ \\
\hline 2011 & $7,043,008,586$ & $1.22 \%$ & $84,839,427$ & 47 & $3,648,252,270$ & $52 \%$ \\
\hline 2010 & $6,958,169,159$ & $1.23 \%$ & $84,428,105$ & 47 & $3,571,272,167$ & $51 \%$ \\
\hline 2009 & $6,873,741,054$ & $1.24 \%$ & $83,969,801$ & 46 & $3,494,944,744$ & $51 \%$ \\
\hline 2008 & $6,789,771,253$ & $1.24 \%$ & $83,352,660$ & 46 & $3,419,420,251$ & $50 \%$ \\
\hline
\end{tabular}


Table 2: World Population Forecast from year 2020 to year 2050

\begin{tabular}{|c|c|c|c|c|c|c|c|c|}
\hline $\begin{array}{c}\text { Year } \\
\text { (July 1) }\end{array}$ & Population & $\begin{array}{c}\text { Yearly \% } \\
\text { Change }\end{array}$ & $\begin{array}{c}\text { Yearly } \\
\text { Change } \\
\end{array}$ & $\begin{array}{c}\text { Median } \\
\text { Age }\end{array}$ & \begin{tabular}{|c|} 
Fertility \\
Rate \\
\end{tabular} & \begin{tabular}{|c|} 
Density \\
$\left(\mathbf{P} / \mathbf{K m}^{2}\right)$ \\
\end{tabular} & $\begin{array}{l}\text { Urban } \\
\text { Pop \% } \\
\end{array}$ & Urban Pop \\
\hline 2020 & $7,795,482,309$ & $1.09 \%$ & $82,494,698$ & 31 & 2.47 & 52 & $55.6 \%$ & $4,338,014,924$ \\
\hline 2025 & $8,185,613,757$ & $0.98 \%$ & $78,026,290$ & 32 & 2.43 & 55 & $57.5 \%$ & $4,705,773,576$ \\
\hline 2030 & $8,551,198,644$ & $0.88 \%$ & $73,116,977$ & 33 & 2.39 & 57 & $59.2 \%$ & $\begin{array}{l}5,058,158,460 \\
\end{array}$ \\
\hline 2035 & $8,892,701,940$ & $0.79 \%$ & $68,300,659$ & 34 & 2.35 & 60 & $60.7 \%$ & $5,394,234,712$ \\
\hline 2040 & $9,210,337,004$ & $0.70 \%$ & $63,527,013$ & 35 & 2.31 & 62 & $62.1 \%$ & $5,715,413,029$ \\
\hline 2045 & $9,504,209,572$ & $0.63 \%$ & $58,774,514$ & 35 & 2.27 & 64 & $63.5 \%$ & $6,030,924,065$ \\
\hline 2050 & $9,771,822,753$ & $0.56 \%$ & $53,522,636$ & 36 & 2.24 & 66 & $64.9 \%$ & $6,338,611,492$ \\
\hline
\end{tabular}

Source: Worldometers (2018, August 25)

It is important to note that these population forecasts posit that ten countries will account for $64 \%$ of this projected world population increase. According to United Nations world population prospects of 2017, countries like Egypt, Pakistan, Democratic Republic of the Congo, Bangladesh, Uganda, Ethiopia, India, China, United States of America and Nigeria, owing to their population tendencies, will contribute immensely to population overshoot by year 2050 (United Nations, 2017; Alexander, 2018). Nigeria in particular is currently posting the fastest rate of population growth worldwide, and is expected to contribute $19 \%$ to this population increase if current birthrate trends persist (Jurczynska, 2013; McCarthy, 2017).

The United Nations population division projects that the overall population of Nigeria, which is currently $195,875,237$, will increase exponentially to about 410 million by the end of the year 2050, and to over 700 million by years 2100 , if the current figures continue. With these numbers, Nigeria will become the third most populated country in the entire world, surpassing the United States in the near future (UN, 2017; World Population Review, 2018). The following infographic by Statista, a leading statistics research institution, shows the world's most populous nations in 2050 created using the UN's population data.

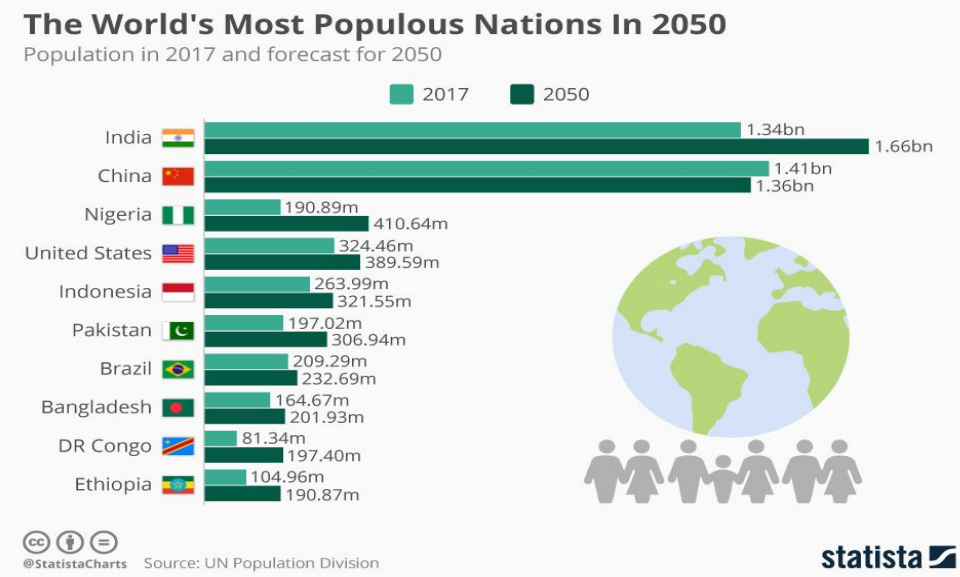

Source: UN Population division (2017) and McCarthy (2017) 
From the figure above, the potential increase of Nigeria's population from 190.89 million in 2017 to 410.64 million in 2050 can be seen. The explanations for this rapid growth vary; some scholars such as Choucri (1983), Urdal (2007), Bretschger (2008) posit that fertility rate, international as well as internal migration from rural to urban centers, changes in the ethnic, religious and racial composition of a population, amongst many other factors, account for rapid population increase. The United Nations population division (2017) cited high fertility rates, high infant mortality rates and the cultural value of large families as factors driving Nigeria's population boom. For Theodore (2006) Religious doctrines, poor education on implications of unplanned families, male-child preference, old age social (in)security and poor health care systems account for the uncontrolled population growth in Nigeria. While all these arguments are tenable, the concern however is what this statistics on ground mean for peace and stability in Nigeria particularly in the face of poor economic policies, high unemployment rate, housing deficits, dearth of infrastructure, etc, coupled with the present inability of the Nigerian state to make sustainable population management policies.

\section{Theoretical Framework}

The thesis of this paper is hinged on the demographic theory of conflict which postulates that rapidly expanding population and scarcity of resources are sources of violent conflict. Thomas Malthus (1766-1834), a foremost scholar of the demographic theory, argued in his work "An Essay on the Principle of Population", that population growth eventually will place catastrophic pressure on resource use leading to famines, conflict, and other stress. Green (2005) noted that the Malthusian theory of conflict connects the contradictions between population growth and the society's ability to ensure adequate minimum means of subsistence for the rapidly growing population to the prevalence of conflict in the society. A variant of this theory, the youth bulge perspective, proposed by the German Social scientist, Gunnar Heinsohn in the mid-1990s, and refined by Gary Fuller and Jack Goldstone have also argued that the disproportion between the rapidly growing youth population and the number of positions and opportunities for sustainable livelihood available to them in society is a major catalyst of the different forms of social unrest in human societies. Neo-Malthusian scholars, such as Robert Kaplan and Thomas Fraser have expanded Malthus' ideas to more than just food, but to also competition for energy resources, arable land, political control, etc. They argue that wars and civil violence will increase as food, clean air, fuel, and suitable farmland become scarcer.

This theory explains the Herdsmen-Farmers conflict situation in Nigeria, especially as competition for resources and space highlights the HerdsmenFarmers crisis. While various structural factors explain the Herders-Farmers crisis, rapid population growth and the attendant resource scarcity, including environmental degradation, industrialization, etc, have fostered conditions conducive to conflict generation and intensification. Blench (2010) have 
posited that the rise in natural resource conflicts is as a result of human population increase and the globalization of the economy and this demographic change remains the most preponderant source of the Herdsmen-Farmers conflict in Nigeria.

\section{Population dimensions of conflict and Nigeria's Herders-Farmers crisis}

While a number of factors have been identified as sources of conflict, the rapidity of population growth in the developing countries has been identified to present its own set of challenges. Population increases have been suspected to have an impact on virtually every environmental, health, education, economic and gender equity concern in the world, especially in countries with stressed resources (Population Institute, 2007). John Wilmoth, the director of the population division in the UN's department of economic and social affairs, noted that this situation makes it more difficult to eradicate poverty and inequality, to combat hunger and malnutrition, and to expand educational enrolment and health systems, all of which are crucial to the success of the new sustainable development agenda (Jones \& Anderson, 2015). Bretschger (2008) and Dimick (2014) posit that the phenomenon of rapid increase in human population over the past three centuries raises concerns that the world may not be able to sustain present or future numbers of inhabitants. Arguments have been put forward that many environmental problems, such as rising levels of atmospheric carbon dioxide, global warming, and pollution, are aggravated by the population expansion (Bretschger, 2008; Dimick, 2014). Other problems associated with overpopulation include the increased demand for resources such as fresh water and food, starvation and malnutrition, consumption of natural resources (such as fossil fuels) faster than the rate of regeneration as well as rapid deterioration in living conditions.

There is also a strong correlation between overpopulation and conflict (Urdal, 2007; Bretschger, 2008; Dimick, 2014). Choucri (1983) noted that while the absence of population related pressures does not guarantee peace, pressures from overwhelming population could increase the probability of conflict. This is particularly true when additional aggravating factors such as widening economic disparities, weak infrastructure, worsening environmental conditions and dwindling natural resources are also present. Angola and Sudan, for example, are commonly cited extreme examples of low-income countries under population and resource scarcity stress. The list also includes Haiti, the Central African Republic, Somalia, the Solomon Islands and Myanmar. In all of these cases, empirical evidences reveal that population density taxes available space and resources, thereby undermining stability (Population Institute, 2007). Urdal (2007) in a time-series study of 27 Indian states for the period of 1956-2002 on sub-national effects of population pressure on violent political conflict, argued that violent conflict is associated with high population pressure on renewable natural resources, with youth bulges and with differential growth rates between ethnic and religious groups. 
This paper sees population increase and resource scarcity as risks of violent conflict in Nigeria, particularly when interacting with high rural population growth, youth bulge and low agricultural yield. The Nigerian Working Group on Peace Building and Governance in a paper released on January 7, 2018, argued that the phenomenal increase of Nigeria's population has put enormous stress on resources used by farmers and pastoralists (Premium Times, 2018). Population increase has evidently led to an expansion in cultivated farmland, a reduction in available grazing land for pastoralists; while the impact of desertification as well as the crisis of energy, which has resulted in deforestation, coupled with climatic uncertainty and lower rainfall have made it more difficult to sustain increasing populations, pushing many farmers and pastoralists with livestock southwards (Nyong \& Fiki, 2005; Premium Times, 2018). One of the many outcomes of this development, according to the Nigerian Working Group on Peace Building and Governance, has been the blockage of transhumance routes, loss of grazing land to agricultural expansion and the increased southward movement of pastoralists which has resulted in severe conflict with local communities. This is particularly the case in communities in Plateau, Kaduna, Niger, Nasarawa, Benue, Taraba and Adamawa States.

\section{Conclusion}

This paper has identified the Herdsmen-Farmers crisis in Nigeria as a resourceuse crisis propelled by the uncontrolled population growth phenomenon in the country. As posited by Green (2005), Urdal (2007), Blench (2010) and Dimick (2014), human population increase, especially of the youth population and the economic crisis are the key catalysts of conflict in the society. Relying on the Demographic theory of conflict, this paper explains how the phenomenal increase of Nigeria's population has put enormous stress on resources used by farmers and pastoralists. As noted earlier the population increase in Nigeria has evidently led to an expansion in cultivated farmland to meet the food needs of the society, reduction in available grazing land for pastoralists; while the impact of desertification, deforestation, coupled with climatic uncertainty and lower rainfall have made it more difficult to sustain increasing populations, pushing many farmers and pastoralists with livestock southwards. In line with these issues and the multiplying effect of rapidly growing population and prevalence of conflict in Nigeria, this paper recommends that Nigeria as a country should begin to pay serious attention to the costs and impacts of population growth and create accordingly rights-based population policies that adapts Nigeria's population strength to a positive force for sustainable development. These population policies must include: the establishment of quality and accessible medical facilities that guarantee maternal and child health care and care for the aged; the eradication of gender bias from law, economic opportunity, health, and culture; and most importantly, the integration of education on population, environment, and resource scarcity into school curricula at various levels. 


\section{References}

Alexander, S. (2018, July 11) Do you know these 10 surprising world population facts? Accessed 15th July, 2018 from https://www.one.org/us/2018/07/ 11/10-surprising-population-facts/.

Barbier, E. (1999) Endogenous Growth and Natural Resource Scarcity. Environmental and Resource Economics, 14(1): 51.

Blench, R. (2010) Conflict between Pastoralists and Cultivators in Nigeria. Review paper prepared for DFID, Nigeria. Accessed 15th August, 2016.

Bretschger, L. (2008) "Population growth and natural resource scarcity: longrun development under seemingly unfavourable conditions." CER-ETH Economics working paper series 08/87, CER-ETH - Center of Economic Research (CER-ETH) at ETH Zurich.

Channels Television (2017, January 13) Osun Civil Defence Arrests Suspected Marauding Herdsmen. Accessed 15th June, 2018 from https://www.channelstv.com/2017/01/13/osun-civil-defence-arrests-suspected-maraudingherdsmen/.

Choucri, N. (1983) Population and Conflict: New Dimensions of Population Dynamics. Policy Development Studies. Number 8. http://www.populationsecurity.org/unfpa-84.htm.

Dabelko, G.D. (2011) Population and Conflict: Exploring the Links. Accessed 15th May, 2016 from https://www.wilsoncenter.org/publication/population-and-conflict-exploring-the-links.

Dalhatu, D.D. (2012) "Causes and Effects of Conflict on Nigeria's Development". Multi-disciplinary Journal of Research and Development Perspectives, Cross River: University of Calabar, 1(1).

Davidheiser, M. and Luna, A.M. (2008) From Complementarity to Conflict: A Historical Analysis of Farmer-Fulbe Relations in West Africa. African Journal on Conflict Resolution, 8(1): 77-104.

Dimick, D. (2014, September 21) "As World's Population Booms, Will Its Resources Be Enough for Us?" National Geographic. Retrieved 23 January 2017.

Erondu, C.I. and Nwakanma, E. (2018) "New Dimensions of the Farmers and Herdsmen Crisis in Nigeria and the Implications for Development". African Research Review (AFRREV) VOL. 12(4), ISSN 1994-9057 (Print) ISSN 2070-0083 (Online). DOI: http://dx.doi.org/10.4314/afrrev.v12i4.2.

Green, B.E. (2005) A General Model of Natural Resource Conflicts: the Case of International Freshwater Disputes. Sociológia, 37(3): 227-248.

International Crisis Group (2017) "Herders against farmers: Nigeria's expanding deadly conflict." Accessed 10th June, 2018 from https://www.crisisgroup.org/africa/west-africa/nigeria/252-herders-against-farmers-nigerias-expanding-deadly-conflict.

Jones, S. and Anderson, M. (2015, July 29) Global population set to hit 9.7 billion people by 2050 despite fall in fertility. Accessed from Guardian News 21st May, 2018, https://www.theguardian.com/global-development- 
/2015/jul/29/un-world-population-prospects-the-2015-revision-9-7-billion2050-fertility.

Jurczynska, K. (2013, September 13) Say What? More than Half of This Century's Population Growth Will Be in Just 10 Countries. Accessed 15th June, 2018 from https://pai.org/blog/say-what-more-than-half-of-this-centurys-population-growth-will-be-in-just-10-countries/.

Kwaja, C.M.A. and Ademola-Adelehin, B.I. (2018) Responses to conflicts between farmers and herders in the middle belt of Nigeria: Mapping past efforts and opportunities for violence prevention. Policy paper of Forum on Farmer and Herder Relations in Nigeria (FFARN) search for Common Ground. Accessed 3rd June, 2018.

Malthus, T. (1798) An Essay on the Principle of Population as it affects the Future Improvement of Society. London: J. Johnson.

Martin, R. (2011) Population, Environment and Conflict. Accessed 15th June, 2016 from https:/www.populationmatters.org/documents/environment_conflict.pdf.

Maxwell, J.W. and Reuveny, R. (2000) Resource Scarcity and Conflict in Developing Countries. Journal of Peace Research, 37(3): 301-322.

McCarthy, N. (2017, June 23) The World's Most Populous Nations in 2050. Accessed 23rd August, 2017 from https://www.statista.com/chart/9947/the-worlds-most-populous-nations-in-2050/.

Mercy Corps, Abuja (2015) The Economic Costs of Conflict and the Benefits of Peace: Effects of Farmers-Pastoralist Conflict in Nigeria's Middle Belt on State, Sector, and National Economies. Retrieved 20th June, 2016 from https://www.mercycorps.org/sites/default/files/Mercy\%20Corps\%20Nigeri a\%20State $\% 20$ Costs $\% 20$ of $\% 20$ Conflict $\% 20$ Policy $\% 20$ Brief $\% 20 J u l y \% 202$ 015.pdf.

Moritz, M. (2010) Understanding Herder-Farmer Conflicts in West Africa: Outline of a Processual Approach. Human Organization, 69(2): 138-148.

Muzan, A.O. (2014) "Insurgency in Nigeria: Addressing the causes as part of the solution". African Human Rights Law Journal, 14: 217-243. Accessed 25th May 2017, 2018 from https://www.republic.com.ng/aprilmay-2017/fulani-herdsmen-farmers/.

New World Encyclopedia (2016, April 16) War. Accessed 21st June, 2016 from http://www.newworldencyclopedia.org/entry/War.

Nigeria Population (2018, June 16) Retrieved 2018-08-27, from http://worldpopulationreview.com/countries/nigeria-population/.

Nigerian Environmental Study Team (NEST) (1991) "Nigeria's Threatened Environment: A National Profile”. Ibadan: A NEST Publication.

Nwosu, C. (2017, April 23) Between Fulani Herdsmen and Farmers: National Security under Buhari. Accessed on 5th July, 2018 https://www.republic.com.ng/aprilmay-2017/fulani-herdsmen-farmers/.

Nyong, A. and Fiki, C. (2005) Droughts-Related Conflicts, Management and Resolution in the West African Sahel. Human Security and Climate Change International Workshop. Oslo: Gechs, Cicero and PR2O, pp. 5-16. 
Odunsi, W. (2017, Feb 6) How Southern Kaduna crisis started - MACBAN scribe. http://dailypost.ng/2017/02/06/southern-kaduna-crisis-started-macban-scribe/.

Peace Direct (2017, November 20) Nigeria: Conflict profile. Accessed 15th June, 2018 from https://www.peaceinsight.org/conflicts/nigeria/.

Population Institute (2007, July 12) Overpopulation May Lead to Conflict. Accessed 21st June, 2016 from https://www.populationinstitute.org/newsroom/press/view/20/.

Premium Times (2018, January 12) How to resolve herdsmen crisis - Nigerian Working Group https://www.premiumtimesng.com/news/top-news/255364-resolve-herdsmen-crisis-nigerian-working-group.html.

Sinclair, A.R.E. and Fryxell, J.M. (1985) The Sahel of Africa: Ecology of a Disaster. Canadian Journal of Zoology, (63): 989-994.

The Telegraph (2018, June 17) The bloody cattle conflict pushing Nigeria to the edge of civil war. Accessed 21st July, 2018 from https:/www.telegraph.co.uk/news/2018/06/17/battle-scarce-resources-muslim-cattle-herders-christian-farmers/.

Theodore, O.I. (2006) The Effects of Population Growth in Nigeria. Journal of Applied Sciences, 6: 1332-1337. Url: https://scialert.net/abstract/?doi=jas.2006.1332.1337.

United Nations, Department of Economic and Social Affairs, Population Division (2017) World Population Prospects: The 2017 Revision. https://esa.un.org/unpd/wpp/.

United States Agency for International Development (USAID) (1996) FEWS Bulletin, Accessed 25th March, 2016 from Davidheiser, M. and Luna, A.M. (2008) From Complementarity to Conflict: A Historical Analysis of Farmer-Fulbe Relations in West Africa. African Journal on Conflict Resolution, 8(1): 77-104.

Urdal, H. (2007) Demography and Conflict: How Population Pressure and Youth Bulges Affect the Risk of Civil War Environmental Change and Security Program https:/www.wilsoncenter.org/event/demography-andconflict-ho w-population-pressure-and-youth-bulges-affect-the-risk-civilw-ar.

Van den Brink, R., Bromley, D.W. and Chavas, J.P. (1995) The Economics of Cain and Abel: Agro-pastoral property rights in the Sahel. The Journal of Development Studies, 31(3): 373.

Worldometers (2018, August 27) World Population. Accessed 15th September, 2018 from http://www.worldometers.info/world-population/. 